\title{
Tracing Students Attendance During Covid-19 Pandemic by Applying Location Detection Technology
}

\author{
${ }^{1}$ Julaily Aida Jusoh, ${ }^{2}$ Mohamad Amin Firdaus Ramli, ${ }^{3}$ Syarilla Iryani A. Saany, ${ }^{4}$ Ahmad Nazari \\ Mohd Rose ${ }^{5}$ Yousef A.Baker El-Ebiary, ${ }^{6}$ M. Hafiz Yusoff,
}

${ }^{1}$ Dr., Faculty of Informatics and Computing, UniSZA, Malaysia,

${ }^{2}$ Student, Faculty of Informatics and Computing, UniSZA, Malaysia.

${ }^{3}$ Assoc. Prof. Dr., Faculty of Informatics and Computing, UniSZA, Malaysia,

${ }^{4}$ Assoc. Prof. Dr. Dean, Faculty of Informatics and Computing, UniSZA University, Malaysia,

${ }^{5}$ Assoc. Prof. Ts. Dr., Faculty of Informatics and Computing, UniSZA University, Malaysia,

${ }^{6}$ Prof. Dato' Dr., Registrar, Albukhary International University, Malaysia,

1 julaily@unisza.edu.my, ${ }^{2}$ aminfirdaus005@gmail.com, ${ }^{3}$ syarilla@unisza.edu.my, ${ }^{4}$ anm@unisza.edu.my ,

5yousefelebiary@unisza.edu.my , ${ }^{6}$ hafiz.yusoff@aiu.edu.my

\begin{abstract}
The Covid-19 pandemic outbreak has initiated the learning process to switch from face-to-face learning methods to open distance learning. The open distance learning is a concept of students assessing the lectures from different venues. Among the activities that are affected by that change, are the process of recording student's attendance and engagement during the online lectures, as opposed to the normal method of being in the same classroom during the lecture. The Global Positioning System (GPS) is a global navigation satellite system that provides location and time synchronization. This approach can assist lecturers in tracking the position of their students throughout the learning session. The operation of the GPS is based on the trilateration method where the position is determined from the distance measurement to satellites. Therefore, iHadir has been proposed to overcome the issue of tracking the students' attendance. The iHadir is a mobile-based application system that can detect student's location during the learning session. This application can be used as a new alternative in monitoring the student's attendance during online learning. The iHadir will help in increasing the effectiveness of attendance's record during online learning.
\end{abstract}

Keywords

Attendance System, GPS, Covid-19, Mobile Application

Article Received: 10 August 2020, Revised: 25 October 2020, Accepted: 18 November 2020

\section{Introduction}

With the evolution of technology that are increasingly in complexity and sophisticated, the use of smart phone has become the main alternative in managing various life affairs. The smart phone has facilitated various matters such as online banking, reservation, online shopping, writing a note, reminder task and many other task [1]. This improvisation and efficacy on the techniques of assessing data and information, has led to our daily routine to have changed for the betterment and less hassles.

The sophistication of existing technology can be applied in education, such as by processing the student's attendance record based on the current technology. As been widely practiced, most universities or institutions are still using the manual methods in recording and assessing attendance records. For example, a lecturer will call the student's name during the class session or by passing the attendance sheet to the student for signing their attendance without any guidance [2]. This will lead the opportunity for student to cheat on their attendance such as asking a friend to sign for him and at the same time will cause the learning process to be disrupted. But during the pandemic, most universities have switched to online-learning. The methods of monitoring the student's attendance has changed towards the use of google form as attendance record. This approach does not make much difference compared to the use of attendance sheets where students can still deceive their attendance.
Another issue arises when irresponsible students may only fill-in google forms as proof of attending the lectures from online. What might happen next, is that the student might slip out of the online classroom, with no one noticing it. This kind of virtual absentees will create a situation of students with less focused and engaged during the online learning session. So, there is a need for a solution to assist the lecturer in monitoring their students during lecture and motivate lecturer to be more enthusiastic in delivering knowledge during lecture session.

In order to avoid the atmosphere of demotivated and disengaged situation among the students, a mobile application call "iHadir - Student's Presence System with Location Detection" is developed to overcome the issue. The iHadir is a mobile application that can be accessed via electronic device such as smart phone, tablet or laptop. It will detect the real-time location of a student and at same time lecturer can monitor the engagement from the student during the learning. The additional feature from this application, the lecturer can generate the attendance report as a record.

Furthermore, iHadir using Trilateration Method that has complement the GPS a procedure for deciding the real season of an understudy's area during a web based learning meeting. The Trilateration Method is a simple mathematical principle and it works by providing a general location data from the first satellite and combine with the data from the second satellite. It will allow the GPS signal to narrow the 
location or position of a user. Finally, the third satellite will determine the specific accurate location of a user [3]. The implementation of the Trilateration Method has assist iHadir in detecting a real-time location of a student. Therefore, iHadir needs an internet connection to update a GPS current location. Here, the lecturer will recognize the location of student during the lecture session. This approach will prevent them from skipping classes and thus improving their engagement during lectures. Nevertheless, the iHadir can also be applied in the face-to-face learning environment, which will contribute to paperless and green environment The employment of iHadir application in attendance monitoring will create an efficient, healthy, safe and is more relevant during the covid-19 pandemic. The manual method of the taking students' attendance is quite a tedious, as it may lead to loss or misplace of attendance sheet besides student can cheat on their attendance. This manual method may also be time consuming, especially if lecturer is calling the student name for attendance. Hereby, the lecturer can't generate an accurate report of the student attendance. Some university bars students from the final exam, if the students failed to achieve the minimum number attendance for a class. Therefore, if the lectures failed to produce accurate attendance reports, then the practice of barring students from final exam will not be exercised correctly.

\section{GPS Technology}

Nowadays, the technology on how to determine a location is being explored and evolved. Geolocation technology, or also known as geolocation, is often the first approach to provide location-based services. The most widely used positioning technology is GPS, Wi-Fi, Bluetooth, Infrared, Cellular and Radio Frequency Identification (RFID) [4]. Researchers are always working on these technologies to improve services in terms of their accuracy and environmental impacts.

GPS is a technology that globally used around the world. GPS consists of 30 satellites in six different 12-hour orbital paths spaced which is five satellites are in view from every point on the globe [5]. Thera are several methods that can be implemented in GPS. The most common methods are the angle of arrival (AoA), time of arrival (ToA), triangulation, time difference of arrival (TDoA), and trilateration. Trilateration is an alternative method that has been implemented in GPS, and this method is suitable for detecting indoor environment positioning. Trilateration is based on finding the position of GPS devices from the intersection of three satellites. Trilateration works by discovering the real-time position once the location of GPS satellites orbiting the earth. Hereby, the location of user can be detected. In measuring a physical distance, we need to use the signal sent by GPS satellites and the time the signal was sent. Trilateration method uses three nodes to determine the location based on GPS node. The GPS receiver will detect the signals, which will then draw the spheres based distance of the signals [6]. After receiving the three signals, the main intersection from the three spheres will indicate the exact location the device used. Figure 1 depicted the connection of three satellites signal based on trilateration method.

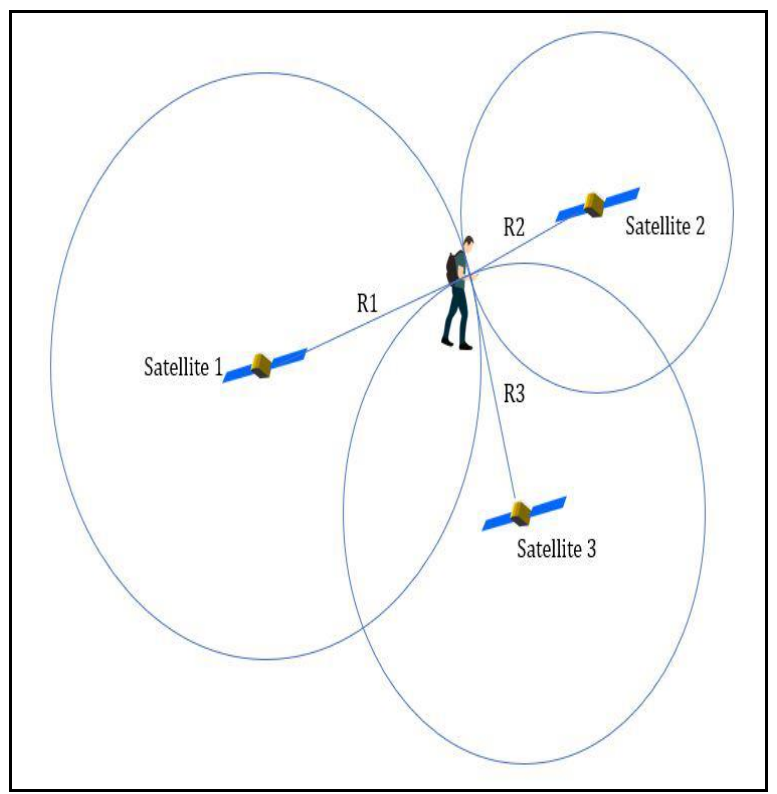

Figure 1: How Trilateration Work By Using Three Satellites Signal

During the location detection process, one of the main problem that may occur is during the situation where the GPS is only good for outdoor environment and poorly progress for indoor environment [3]. The limitation of detecting GPS signal in indoor environment is that it is weak inside the building. The signal cannot penetrate the building wall structures and it will affect the effectiveness of detection a location. With such limitations, it has led the opportunity to explore the appropriate way in detecting a location that will accurately work for indoor environment such as Active Bat. Be that as it may, Active Bat needs numerous roof ultrasound locators which are over the top expensive to introduce. Accordingly, Trilateration technique is appropriate for indoor climate because of a calculation that can utilize WI-FI or Internet passageways to get information. For instance, on the off chance that the collector is a convenient gadget, at that point the sign strength can be utilized to appraise the distance between the passage and the cell phone. With this technique, he can see which passage is being dispensed in the structure. The main advantages of this method as a part of the networking provider on mobile device is the used of WI-FI network points, the strength of received signal [7]. The trilateration method is capable in detecting real-time device location. However, the trilateration method has some shortcomings in distance conversion and its error is very significant to be ignored. Alternatively, it can be overcome by applying a Kalman filter that will improve the accuracy of a location detection.

As for iHadir application, GPS is an appropriate technology to automatically detect the position of the attendees. Using GPS, this application is able to monitor the presence of attendees while overcoming weaknesses in the manual practice. But, internet connectivity (Wi-Fi/3G) is needed for connecting to the database that resides in the remote server. Table 1 shows a comparative study on the previous work that leading to the selection of trilateration method. 
Table 1: Comparative study of GPS technology

\begin{tabular}{|c|c|c|c|}
\hline $\begin{array}{l}\text { Previous } \\
\text { Work }\end{array}$ & Method & Strength & Weakness \\
\hline $\begin{array}{l}\text { GPS: } \\
\text { location- } \\
\text { tracking } \\
\text { technology. } \\
{[10]}\end{array}$ & $\begin{array}{l}\text { Trigalatio } \\
\mathrm{n} \text { and } \\
\text { trilaterati } \\
\text { on } \\
\text { method }\end{array}$ & $\begin{array}{l}\text { Give exact } \\
\text { area data to } \\
\text { moving } \\
\text { articles. }\end{array}$ & $\begin{array}{l}\text { Obstructions } \\
\text { and } \quad \text { weak } \\
\text { signals. }\end{array}$ \\
\hline $\begin{array}{l}\text { Examinatio } \\
\mathrm{n} \text { of inner } \\
\text { limitation } \\
\text { technique: } \\
\text { unique } \\
\text { mark and } \\
\text { triangulatio } \\
\mathrm{n} \\
\text { calculation. } \\
\text { [11] }\end{array}$ & $\begin{array}{l}\text { Fingerpri } \\
\text { nt, } \\
\text { trilaterati } \\
\text { on }\end{array}$ & $\begin{array}{l}\text { Capable to } \\
\text { detect an } \\
\text { exact } \\
\text { location of } \\
\text { indoor } \\
\text { environme } \\
\text { nt }\end{array}$ & $\begin{array}{lr}\text { Need a } & \text { Wi-Fi } \\
\text { based } \\
\text { operate. }\end{array}$ \\
\hline 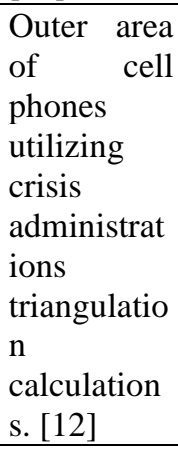 & $\begin{array}{l}\text { GSM, } \\
\text { Angle of } \\
\text { Arrival, } \\
\text { Trilaterat } \\
\text { ion } \\
\text { algorithm } \\
\text {. }\end{array}$ & $\begin{array}{l}\text { Ready to } \\
\text { find a cell } \\
\text { phone } \\
\text { inside a } \\
\text { GSM } \\
\text { network in } \\
\text { a crisis }\end{array}$ & $\begin{array}{l}\text { Just information } \\
\text { extraction from } \\
\text { portable } \\
\text { organizations } \\
\text { utilizes cell } \\
\text { phones with } \\
\text { Android OS } 4.1 \\
\text { or higher. }\end{array}$ \\
\hline $\begin{array}{l}\text { Indoor } \\
\text { position } \\
\text { location } \\
\text { utilizing } \\
\text { Wi-Fi and } \\
\text { triple-party } \\
\text { innovation } \\
{[14] .[14]}\end{array}$ & $\begin{array}{l}\text { Internal } \\
\text { area } \\
\text { recogniti } \\
\text { on, WI- } \\
\text { FI, mount } \\
\text { innovatio } \\
n\end{array}$ & $\begin{array}{l}\text { Calculate } \\
\text { the exact } \\
\text { location of } \\
\text { a user in an } \\
\text { indoor area }\end{array}$ & - \\
\hline $\begin{array}{l}\text { Indoor } \\
\text { location } \\
\text { using } \\
\text { trilateration } \\
\text { characterist } \\
\text { ic. }[15]\end{array}$ & $\begin{array}{l}\text { Trilaterat } \\
\text { ion } \\
\text { method }\end{array}$ & $\begin{array}{l}\text { Estimate } \\
\text { the } \\
\text { generated } \\
\text { position by } \\
\text { the } \\
\text { trilateration } \\
\text { method as } \\
\text { a } \\
\text { characterist } \\
\text { ic of a } \\
\text { location }\end{array}$ & $\begin{array}{l}\text { Only applicable } \\
\text { in } \\
\text { environment }\end{array}$ \\
\hline
\end{tabular}

\section{Existing Attendance System}

In the education sector, students' attendance plays an important role in ensuring student involvement in lectures. It also contributes to the assessment of student comprehension in a subject $[6,7]$. Assessment of student comprehension is closely related to materials taught students during the lecture session. From the observations, students who rarely attend lectures tend to obtain lower marks compared to those who regularly attend the lectures. Therefore, the student attendance management system needs to be enhanced in order to improve student performance especially when conducting online learning.

iHadir is thus more relevant to the pandemic covid-19 situation, whereby the attendance system which includes location detection is more deemed and appropriate. There are several attendance systems that have been developed and the most well-known is the attendance system that implements the electronic card scanning. This system able to speed up the recording and verifying student attendance process. However, the system is not practical during the pandemic as most educational institutions have practiced the online learning. Several examples of existing attendance systems will be discussed in the next section. There are MyAT(MyAttendaceTracker.com), Jojo Times and UniMAP Geo-Location Based Attendance and Analytical System.

\section{i. $\quad$ MyAT(MyAttendaceTracker.com)}

This is a web-based system and it has been developed to support educators in tracking their student attendance in a short time. MyAT use geo-location method using GPS to detect a location of the students [16]. The main features of MyAT are attendance monitoring, parent messaging system and dashboard. The attendance monitoring will provide fast, efficient and reliable attendance analysis and reporting. While the parent messaging, is a communication channel set up between parents and teachers with regards to student's activity in the classroom. It will enhance the parent awareness and be up to date of his son/daughter' $s$ performance and discipline during learning process. The dashboard is like a noticeboard to obtain information pertaining to achievement of the students in the classroom. This system benefits as fast and easy attendance monitoring, parenting messaging system and grade dashboard. Those benefit help the improvement of student success rate.

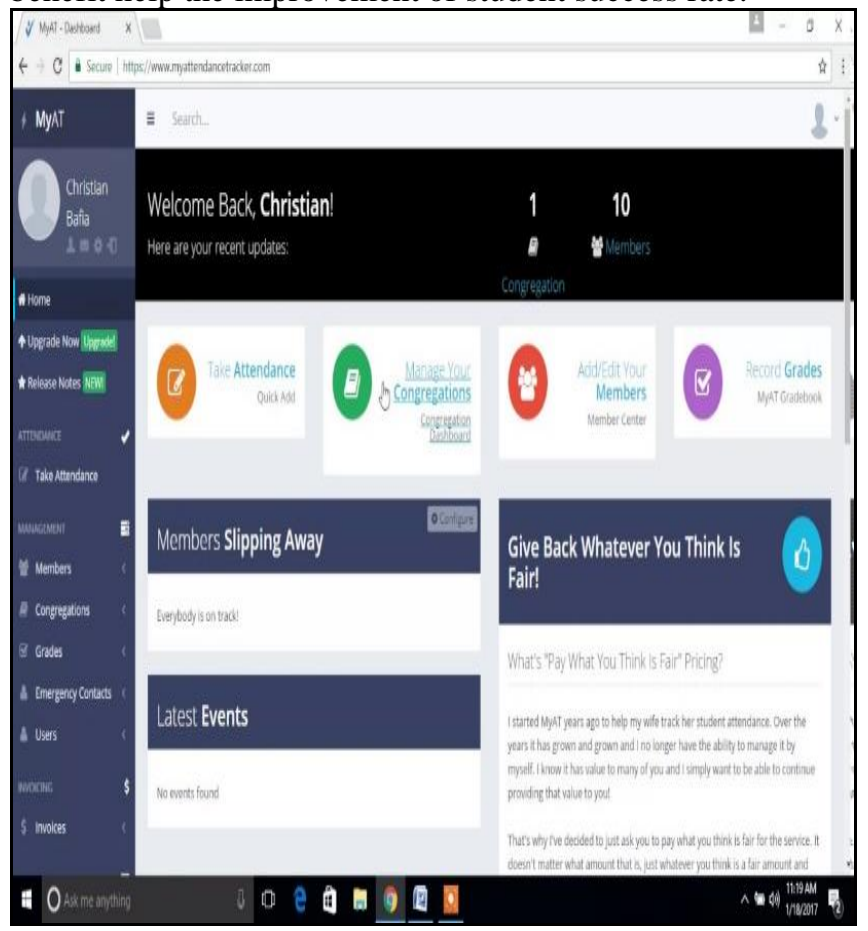

Figure 2 : Example MyAT website Main Page 
ii.

\section{Jojo Times}

Jojo Times is a mobile application that has been used to record attendance for office use. The main feature is tracing an attendance using GPS geo-location, biometric face recognition and fingerprint verification. Figure 3 illustrates the screenshot of this application. This application is useful in monitoring an employee attendance, less time consuming in generating monthly attendance report and producing a very reliable and accurate attendance report [17].

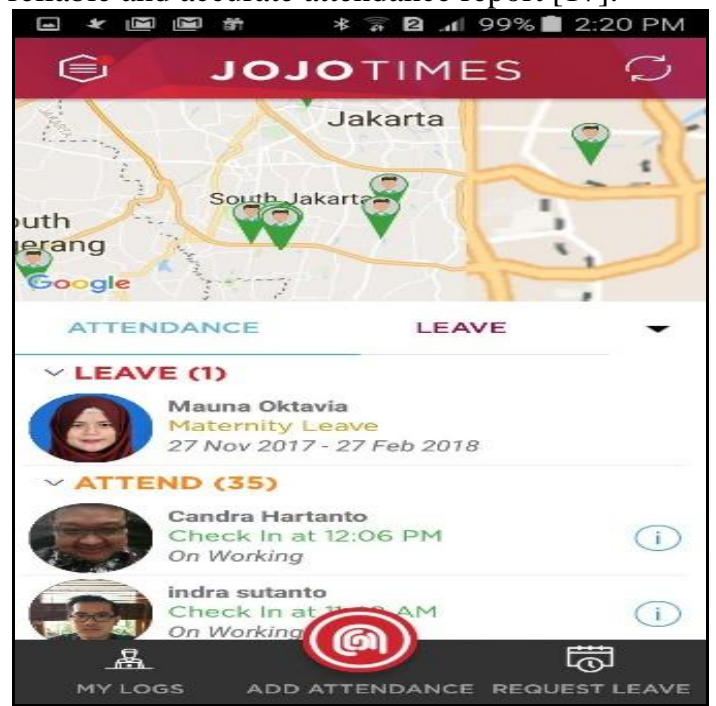

Figure 3 : Example of Jojo Times application

\section{iii. UniMAP Geo-Location Based Attendance and Analytical System}

This is a latest system that has be developed by University Malaysia Perlis (UniMAP). It is developed in order to replace the current attendance system that using Biometric (Thumb Print). It is a web-based system with geo-location tracking technology to monitor and identify geographic location of staff and student. This system is useful in tracking and monitoring their staff and student attendance during pandemic. Figure 4 demonstrates the application features.

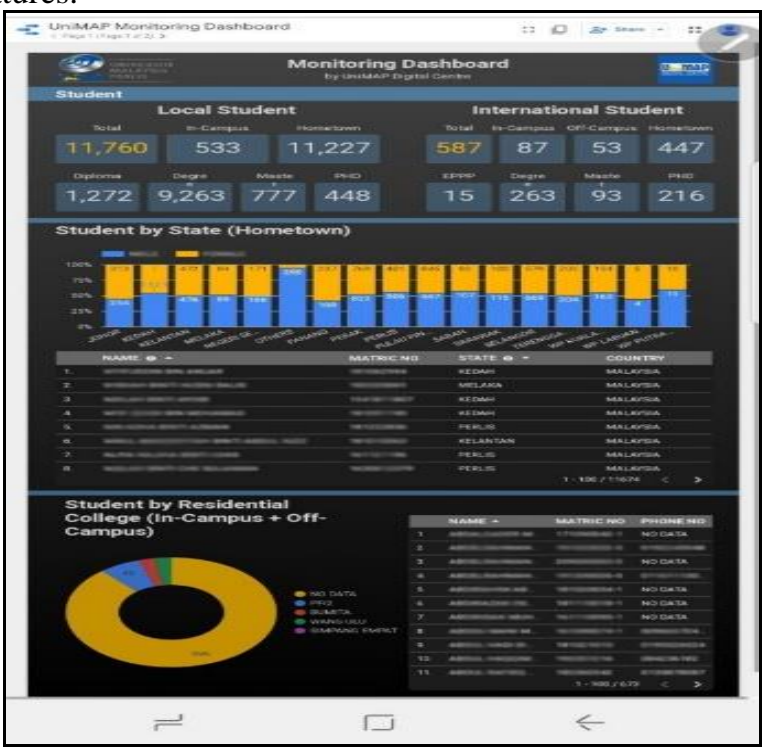

Figure 4: Dashboard of UniMAP Geo-Location Based Attendance and Analytical System

\section{iHADIR FEATURES}

iHadir mobile application is purposely developed for education system to focus on tracing student's attendance by applying location detection technology. It has a simple and advantageous interface and is introduced with an underlying GPS gadget. Then again, worker side incorporates nearby worker, neighborhood data set and distant workers. The customer side will speak with the worker side by means of Wi-Fi association. Figure 5 illustrates the conceptual framework of iHadir application. It shows how the interaction between lecturer and student occurs within the system. In this system student will fill-in the attendance while the system will automatically detect the student's location. Then the lecturer will record the attendance details along with the student's real-time location detected. For the purpose of recording and data analyzing, all of the data and information will be stored in database. The app is designed to be flexible, easy-to-use, portable, and supports dynamic information.

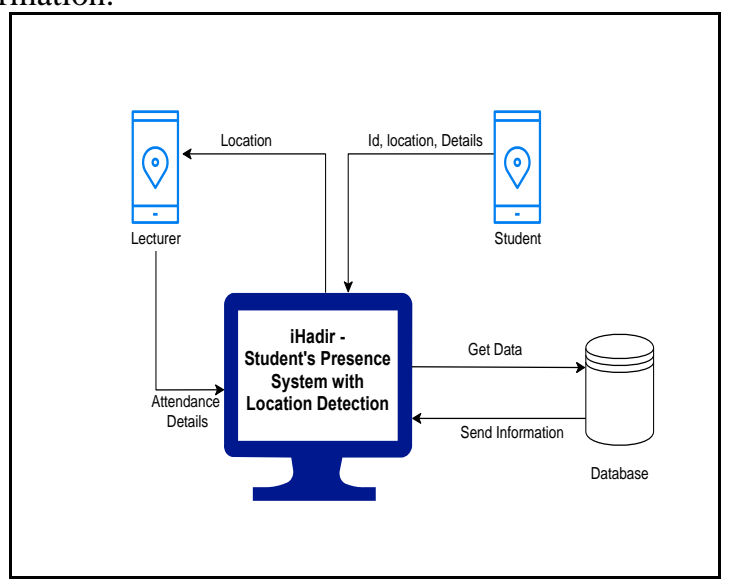

Figure 5: Framework for iHadir System

This application only allows authorized users of the related lectures and subjects to utilize the provided features. Each authorized user has to create an account to access the application. Figure 6 illustrates the main page of iHadir application while Figure 7 shows lectures profile of iHadir application. The main function at the lecturer section in this application is to enable lecturers to manage the lecture details for assisting students to record their attendance.

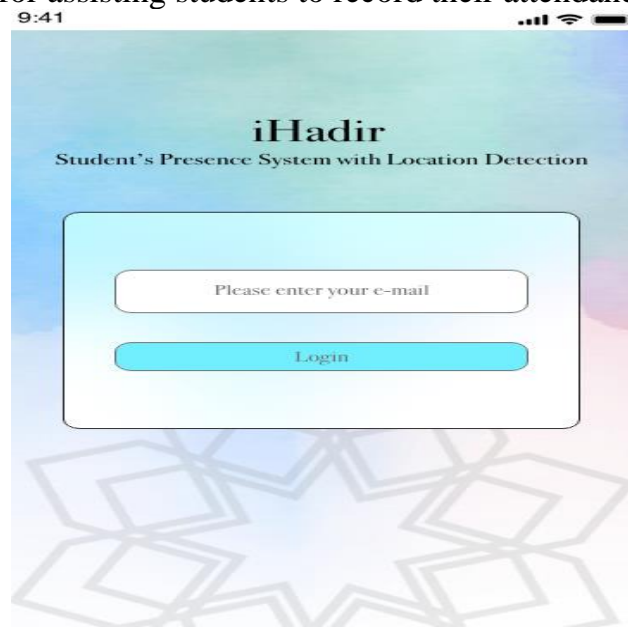

Figure 6: The main page for iHadir System 


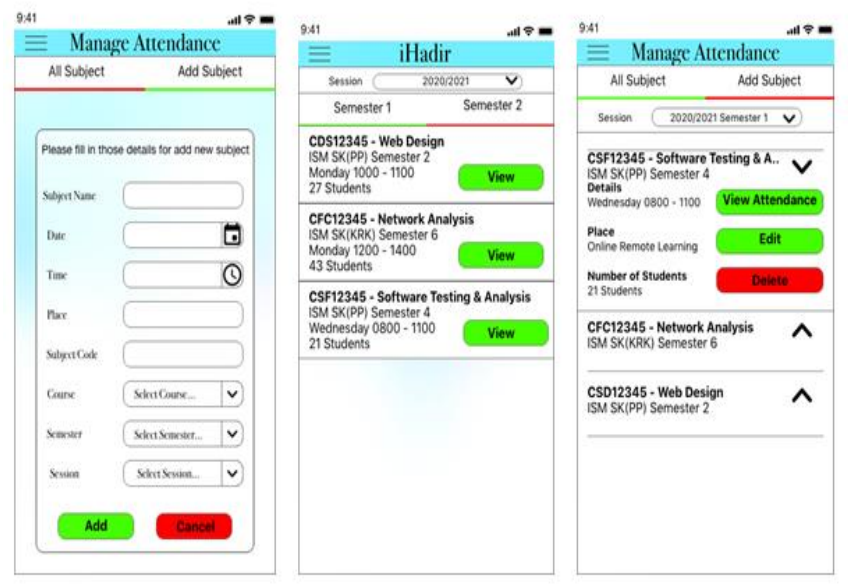

Figure 6: The lectures profile for iHadir System

As depicted in the above figure, the lecturer can view the list of lectures that have been registered or added in this application by academic's semester. In addition, during the online learning session, the lecturer can view the number of engagement and also the location of the student's during the class.

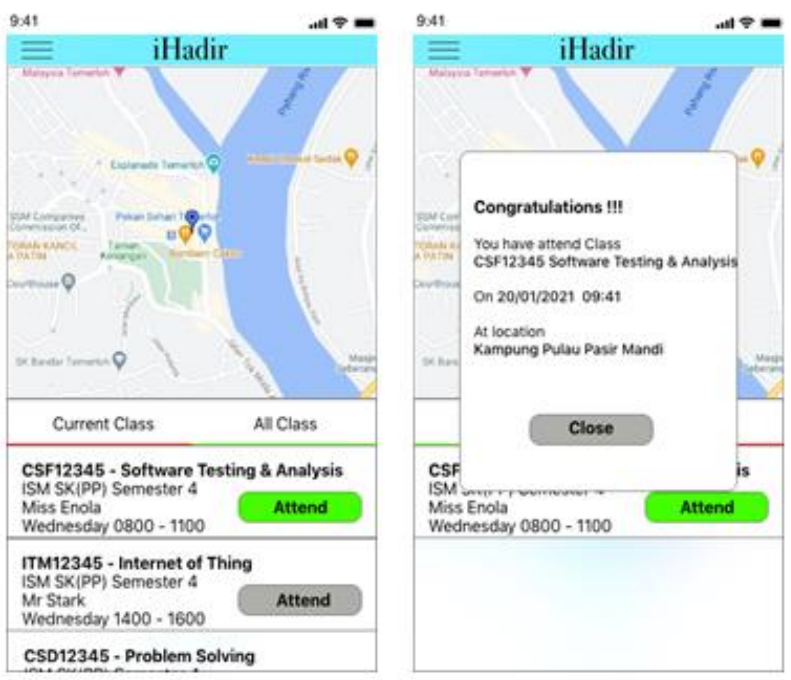

Figure 6: The student view for iHadir System

In the student section, students can view and select lectures according to the schedule that has been set for each subject. To record attendance, students need to activate the location mode on their smartphone to enable the application to detect the location of the student's presence at that time.

\section{Conclusion}

This study presents the development and deployment of the iHadir application in ensuring that the student's attendance monitoring is more efficient, secured and most importantly, to prevent from missing the lectures by feeding false information to the attendance recording system. iHadir application provides lecture and attendance information through the stylish and user-friendly GUI. In addition, the system is available with the maps that provide accurate location. For future works, this study will integrate the information and link to the assessment marks system

\section{References}

[1] Odin, MS, Aliar, SM, DAS, NC, and Talukder, FA (2014). Attendance and departure system depends on location. International Journal of Computer Theory and Engineering, 6 (1), 36.

[2] R. Bajaj, S. L. Ranaweera and D. P. Agrawal, "GPS: location-tracking technology," in Computer, vol. 35, no. 4, pp. 92-94, March 2002, doi: 10.1109 / MC.2002.993780.

[3] Wei, T., \& Bell, S. (2011). Comparison of internal localization method: fingerprint and triangulation algorithm. University of Saskatchewan. Accessed March 24, 2015.

[4] Rajesh, D. A., Shivaji, G. P., Chandrashekhar, N. P., \& Arya, C. S. Attendance System Using RFID and Fingerprint with Location Detection.

[5] L. E. Navarro-Serment, C. J. J. Paredis and P. K. Khosla, "A beacon system for the localization of distributed robotic teams", Proc. Int. Conf. Field Service Robot., vol. 6, pp. 1-6, 1999.

[6] Yao, J. F. J., \& Chiang, T. M. (2011). Correlation between class attendance and grade. Journal of Computing Sciences in Colleges, 27(2), 142-147.

[7] Shoewu, O. S. O., \& Lawson, A. L. A. (2011). Embedded Computer-Based Lecture Attendance Based Lecture Attendance Management System Management System. African Journal of Computing \& ICT September, 4(3), 27-36.

[8] Yousef A.Baker El-Ebiary, Samer Bamansoor, Waheeb Abu-Ulbeh, Wan Mohd Amir, Syarilla Iryani A. Saany, M. Hafiz Yusoff. "Using Interval Manager Mobile Application in Saving Time and Cost" Vol. 68, Editor's Issues, Oct. 2020, pp. 82-85, IJETT, Doi: 10.14445/22315381/CATI1P214.

[9] Cook, B., Buckberry, G., Scowcroft, I., Mitchell, J., \& Allen, T. (2005, September). Indoor location using trilateration characteristics. In Proc. 
london communications symposium (pp. 147-150).

[10] Syarilla Iryani A. Saany, Elsayed M. S. S. Elawadi, Yasser M. Tarshany, M. Hafiz Yusoff, Yousef A.Baker El-Ebiary, Nur Hikmah Binti Ismail. (2020). Utilizing the AR and Mobile Apps to Show the Rhetorical Miracle of the Fetal Growth Stages According Quran. IJFGCN, 13(3), 1068-1081.

[11] Yousef A.Baker El-Ebiary, Samer Bamansoor, Waheeb Abu-Ulbeh, Wan Mohd Amir, Syarilla Iryani A. Saany, M. Hafiz Yusoff. "A Prognosis of Chinese EGovernance" Vol. 68, Editor's Issues, Oct. 2020, pp. 86-89, IJETT, doi: 10.14445/22315381/CATI1P215.

[12] W. M. Amir Fazamin W. Hamzah, Waheeb Abu-Ulbeh, Najeeb Abbas AlSammarraie, Yousef A.Baker El-Ebiary, M. Hafiz Yusoff, Syarilla Iryani A. Saany, Azliza Yacob. "The Integration of Learning Management Systems with PLE - a Review Paper" Vol. 68, Editor's Issues, Oct. 2020, pp. 94-96, IJETT, doi: 10.14445/22315381/CATI1P217.

[13] Chandramohan, J., Nagarajan, R., Dineshkumar, T., Kannan, G., and Prakash, R. (2017). Understudy participation observing framework dependent on biometric global positioning framework and GPS. Worldwide Journal of Advanced Engineering, Management and Science, (3), 239799.

[14] Camellia, L. ， Hamidi, I.A.D, Dharmalexana, and W. , And a tick, prof. (2018, July) Real-time online presence framework dependent on unique mark and GPS in cell phone. At the 2018 Fourth International Conference on Wireless and Telematics (ICWT) (pages 1-4). IEEE.

[15] Ayop, Z., Yee, C., Anawar, S., Hamid, E., and Syahrul, M. (2018). Area mindful occasion participation framework utilizing QR code and GPS innovation. Worldwide Journal of Advanced Computer Science and Applications, (9), 466-473.
[16] Jones, Dr. (2011). How GPs can help decrease improper participation. Crisis nurture, 19 (4).

[17] Soewito, B., Gaol, F. L., Simanjuntak, E., and Gunawan, F.E (2015, August). Participation framework on your Android cell phone. In the 2015 International Conference on Control, Electronics, Renewable Energy and Communications (ICCEREC) (pp. 208-211). IEEE. 